\title{
The Culture Variable Vis-à-Vis Anti-bribery Law: A Grey Area in Transnational Corporate Criminal Liability
}

\author{
Qingxiu Bu ${ }^{1}$
}

Published online: 6 October 2017

(C) The Author(s) 2017. This article is an open access publication

\begin{abstract}
Cross-border transactions are generating corresponding globalisation of law enforcement efforts. Culture has significantly influenced the legal analysis of anti-bribery law. With the increase of transnational bribery, benefits from globalisation will be undermined unless an effective legal regime can mitigate the harm of bribery. It is perceived that corruption in China is more prevalent than in the West given its embedded place in Chinese culture. It is further alleged that Chinese multinational companies (MNCs) are taking advantage of an unlevel playing field, as they are not subject to stringently-enforced anti-bribery laws. This hypothesis creates a myriad of anti-bribery problems in terms of legislation and enforcement, which particularly manifest in China's perceived cultural toleration of bribery. Cultural assumptions undermine the global anti-bribery regime and compromise potential collaborative anti-bribery efforts across jurisdictions in a rapidly globalizing world. The Chinese culture does not necessarily impede China's criminalisation of paying bribes to foreign officials. It is argued that the cultural role should not be overestimated, otherwise the hazard of the ethnocentric engagement with the Chinese culture would affect the ability of foreign MNCs to integrate their global compliance programmes. Multinationals can only mitigate their exposure to criminal liability globally, provided that they comply robustly with anti-bribery laws of both home and host jurisdictions.
\end{abstract}

Keywords Culture · Guanxi · Bribery · Corruption · Corporate criminal liability · Global compliance

Qingxiu Bu

Q.Bu@ sussex.ac.uk

1 Associate Professor, Sussex Law School, University of Sussex, Falmer, UK 


\section{Introduction}

Bribery contradicts the notion of the free market characterised by transparency and fair competition. It subverts the trust between businesses and governments around the world. ${ }^{1}$ Bribery is not in China's national interest. Pervasive corruption will inexorably undermine respect for the rule of law, generating serious distortions in the efficiency and fairness of the Chinese society. ${ }^{2}$ As a powerful driving force reshaping the world in the twenty first century, globalisation inevitably brings transnational bribery with multinational company (MNC) transactions stretching across borders. ${ }^{3}$ It is critical that there is no legal globalisation. ${ }^{4}$ The accelerating rate of globalisation has been accompanied by heightened awareness of differing attributes and values in regards to bribery. ${ }^{5}$ A deep-rooted culture of gift-giving tests the boundaries of Western moral, ethical and financial best practice principles. It poses a substantial challenge for Western MNCs in a culture that relies heavily on guanxi. Western multinationals, which run with strict policies on gifts and hospitality, may find it difficult to uphold their global compliance codes in China. The paradoxical cultural acceptance of bribery challenges the efficacy of major antibribery regimes, such as the US Foreign Corrupt Practices Act (FCPA) and the UK Bribery Act (BA 2010). The fierce competition for securing business opportunities in China's lucrative markets escalates the pressure on those Western MNCs. It has sparked a long standing debate over whether extraterritorial restrictions on bribery are viable, or whether the cultural variable will influence the globalisation of antibribery regimes. ${ }^{6}$ It remains a myth in terms of the extent to which how the Chinese culture interacts with the anti-bribery globalisation. It is worth exploring whether the perceived concerns constitute a real challenge and the extent to which the culture affects the globalisation of anti-bribery legislation and implementation.

This study is in five parts. Section 2 provides an overview of China's unique legal culture of guanxi and gift-giving inherent from the nation's cultural underpinnings of Confucianism. Arguably, bribery is not rooted in the Chinese culture, rather a result of rational and economic calculation within context of time and location. It is an efficient institution that matters, which may account for why China was given lower ranking in the Corruption Perceptions Index (CPI 2015) than those in Hong Kong and Singapore, despite their sharing similarities in culture. Section 3 discusses the Amendments made to Article 164 of the PRC Criminal Law which criminalises bribery beyond China's borders. Section 4 continues to discuss developments in the sections of Chinese Criminal Law focused on targeting bribers. The section continues to look into the far-reaching impact of the Amendments on both foreign and domestic MNCs. Section 4 provides a critique on the effectiveness of the FCPA and Bribery Act 2010. Given the intrinsic nature and extrinsic need to build business

\footnotetext{
${ }^{1}$ Organisation for Economic Co-operation and Development (OECD 2014).

${ }^{2}$ Rose-Ackerman (2010).

${ }^{3}$ Nichols (1999c), p 271.

${ }^{4}$ Michaels (2013).

${ }^{5}$ Stolenberg (2000), p 725.

${ }^{6}$ Salbu (1999).
} 
relations regardless of jurisdictions, the recent Guidance to the two statutes are examined to ascertain whether statutory deterrence against bribery has been weakened. The rationales enshrined in the Guidance do not justify the softened approaches in the jurisdictions of the UK and the US. Section 5 explicates plausible perceptions of cultural impacts on anti-bribery regimes, and the controversies that flow from the gap between them. With this pseudo-proposition rebutted, it is instead proposed that efficient anti-bribery laws can curb corporate offences, without placing foreign MNCs at a severe competitive disadvantage. Section 6 explores a viable governance regime under which MNCs may reduce its exposure to criminal liability. It further examines the extent to which the variable of culture can influence MNCs' global compliance programmes, and the feasibility in fostering a compliance culture against bribery. At stake is the potential to develop global anti-bribery compliance programmes that are compatible with local legal and regulatory settings.

\section{The Main-Theme of Culture: Guanxi}

Perceptions of bribery do not vary much by culture. Confucianism, deeply embedded in Chinese society, condemns bribery as other civilisations commonly do. ${ }^{7}$ The Confucian ideology not only discourages corruption by advocating integrity and morality, but also stresses the importance of human relationships. ${ }^{8}$ The principles of reciprocity and trust espoused in Confucianism are manifest in guanxi, which implies a continuous exchange of favours. ${ }^{9}$ These notions determine how a person should act within a community. ${ }^{10}$ As Chinese society slides into mercantilism, gift giving has long been a component of business operations. ${ }^{11}$ Ethical concerns arise due to an improper application of guanxi, which often leads to bribery. In this vein, guanxi helps to ascertain the prevalence of the corruption epidemic, which is intrinsically bound within the cultural norms of Chinese society.

\subsection{Guanxi with Unique Chinese Characteristics}

China is experiencing a period of transition to a market economy, shifting from a guanxi predominance to an orientation characterised by the rule of law. ${ }^{12}$ Nevertheless, guanxi still explicitly exemplifies a continued predominance of act utilitarianism over the weaker rule utilitarianism in China. ${ }^{13}$ The art of guanxi is widely perceived to be a negative phenomenon; the corruption of officialdom in

\footnotetext{
7 Nichols (1999c).

8 Stolenberg (2000), p 722.

9 Pearce and Xin (1996).

10 Stolenberg (2000).

11 Steidlmeier (1999).

12 Nichols (1999a).

13 Hansen (1992), pp 115-121.
} 
contemporary Chinese society. ${ }^{14}$ Across the globe, attitudes towards what exactly bribery comprises vary. Given the inherent conflict between the socially-embedded nature of some common practice and legal definitions of bribery, it makes sense to distinguish culturally appropriate gift giving from outright bribery.

\subsubsection{Is Guanxi-Oriented Culture Inherently Wrong?}

Guanxi per se has no original sin. It is a deeply embedded system of interpersonal relationships. As Hamilton observed: 'Chinese society consists of networks of people whose actions are oriented by normative social relationships. ${ }^{15}$ A pragmatic theory holds that guanxi is used to build privileged networks to secure potential advantages; the recipient of a gift obligates themselves to return the favour in the form of an undefined reciprocal service in the future. Guanxi falls in line with Confucian benevolence, which expects the recipient to repay favours. It is this reciprocating dimension that ensures respect of the guanxi obligations within the network. Guanxi, in this dimension of the Chinese culture, acts as a means to advance personal interests. Gift-giving can serve as a facilitating scheme in the guanxi-related context. Apart from the pragmatic perspective, guanxi functions as an efficient coordination mechanism, which ostensibly lowers transaction costs in a transitional period characterised by high institutional uncertainty. ${ }^{16}$ It makes up for the defectiveness of an incomplete market economy. ${ }^{17}$ Theoretically, bribery is inversely proportional to its costs. As the costs associated with corrupt transactions increase, guanxi gradually reduces in importance, and incidences of bribery should decline. However, this has not been the case during China's transition to a market economy. With central-administrative mechanisms diminishing, new marketoriented substitutes are emerging placed to effectively govern the transition. ${ }^{18}$ The growing liberalisation of the Chinese economy demands a well-established anti-bribery regime, which can provide legal certainty, and thus steadily eliminate reliance on guanxi to safeguard transactions. The mere institutionalisation of sophisticated laws does not displace the reliance on guanxi in the short term. There should be a common consensus among businesses that regulatory regimes perform more effectively than guanxi, before they could be viewed as preferable in regulating their transactions. ${ }^{19}$

\subsubsection{Pluralistic Attitudes towards Bribery-The Cultural Tolerance of Bribery in China}

Guanxi-based bribery has been increasingly common in contemporary Chinese society. As a form of significant social capital, guanxi is cultivated over time based

\footnotetext{
14 Yang (1994), pp 56-62.

15 Hamilton (2006), p 45.

16 Schramm and Taube (2003).

17 Zhan (2012).

18 Posner (1980).

19 Richardson and Tepikina (2014).
} 
on trust and reciprocity, which may facilitate binding bribery. ${ }^{20}$ The cultural tolerance of corruption may partly account for the complexity of anti-bribery efforts in China. Firstly, sentiments of moral repugnance and censure towards corruption are not so prevalent in China as in Western countries. ${ }^{21}$ Chinese culture indicates that people's social status rests overwhelmingly with their wealth, which incentivises people to pursue even illicit gains at any expense. Bribery per se serves as a symptom of both opportunity and lack of restraint. The restraints on such activities have eroded as China's guiding ideology has shifted from one of social purification to one of overwhelming materialism. ${ }^{22}$ Such a perception affects the public's attitude towards corruption. Secondly, sensitivity to culture in China leads to tolerance of certain actions that may be labelled as bribery under the BA 2010 and the FCPA. ${ }^{23}$ Gift giving is fundamental to the entrenched practice of developing guanxi and plays a delicate role in securing a potential business. ${ }^{24}$ Gifts foster a sense of indebtedness. ${ }^{25}$ A common form of quid pro quo relational expectations is evinced via tacit understanding. As a result, bribery is plausibly accepted as valid means in conducting business, running rampant throughout China. Guanxi is often abused to advance the interests of firms at the price of distorting the commercial culture. $^{26}$ It was indicated that $94.2 \%$ of participants prosecuted for bribe-giving said that they would warm up relations with guanxi prior to conducting bribery. ${ }^{27}$ For this reason, culturally-competent MNCs should become aware of its ethical and legal ramifications. Furthermore, cultural differences render it difficult to distinguish between actionable and acceptable behaviour, ${ }^{28}$ blurring the line between regular transactions and bribery in the current hybrid system. The issue arises as to where the line should be drawn. ${ }^{29}$ Noonan suggests that:

a gift is given in a context created by personal relations to convey a personal feeling and concluding that a gift-giver does not give by way of compensation or by way of purchase. ${ }^{30}$

It depends largely on whether a reasonable person would regard a gift as unduly extravagant in particular circumstances. ${ }^{31}$ Within Chinese culture, there are moral parameters in distinguishing regular gift-giving from bribery, based on 'intentions,

\footnotetext{
20 Hsu (2005).

$21 \mathrm{Li}(2011)$.

22 Stolenberg (2000).

23 Rose-Ackerman (2010).

24 Smart and Hsu (2007).

25 Marcoux (2009).

26 Silver-Greenberg and Protess (2013).

27 Li (2011).

28 Salbu (1999), pp 240-241.

29 Ibid., at p 250.

30 Noonan (1984), p 695.

31 Security Exchange Commission (SEC) and Department of Justice (DoJ), A Resource Guide to the US Foreign Corrupt Practices Act (14 November 2012), http://www.justice.gov/sites/default/files/criminalfraud/legacy/2015/01/16/guide.pdf, pp 15-18 ('FCPA Guidance').
} 
purpose, means, and the result'. ${ }^{32}$ These ideological differences in value and western ethnocentric prejudice often lead to the assumption that China does not regard the act of bribery as shameful in the way Westerners regard it. ${ }^{33}$ Guthrie raised a counterargument refuting this presumption that:

powerful economic actors often pay increasing attention to the laws, rules and regulations that are part of the emerging rational-legal system which is being constructed by the Chinese state. ${ }^{34}$

Chinese culture has steadily taken on a new lens, aligned with a more Western view on bribery. Never before in China has the practice of gift-giving come under such stringent scrutiny. Foreign MNCs' policy against bribery must apply the same in China, despite different presuppositions.

\subsection{Counterargument: Bribery is the Result of a Rational and Economic Calculation}

Bribery is not simply cultural but also rests upon cost and benefit calculations, which are made by those who believe that the potential gains sufficiently outweigh any possible penalty. MNCs will pay bribes unless the potential rewards are trivial and the risks disproportionately substantial. As rational calculators, they apply a cost-benefit analysis when deciding whether to engage in bribery, which occurs only where the anticipated illicit gains exceed the anticipated costs of penalty. Judge Richard Posner once stated that: 'the primary function of law, in an economic perspective, is to alter incentives. ${ }^{35}$ One way to deter bribery is to mitigate the incentives of the briber by stripping away their potential gains. ${ }^{36}$ Theoretically, penalties can enhance their deterrent force by depriving bribers of their incentives in engaging with bribery. An optimal deterrent penalty scheme would set the level of punishment at the level of the marginal cost of bribery. ${ }^{37}$ It can be achieved by making bribery too costly to conduct. ${ }^{38}$ After all, marginal benefits increase as the probability of preventing a case of bribery falls. Without the genuine threat of criminal liability, MNCs have little incentive to comply with law when the fines imposed make up a fraction of the potential illicit gains procured through bribery.

\subsection{The Dialectical Analysis of Guanxi in Comparison: The Institutional Void}

It is an institutional void that contributes primarily to prevalent bribery in China. Corruption is pervasive with tentacles reaching into every arena of Chinese

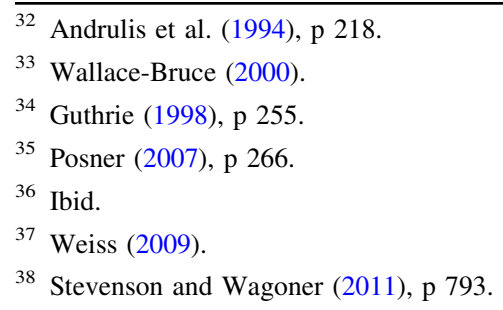


society. ${ }^{39}$ Because of the culture of gift-giving, the Chinese have been accused of being promiscuously corrupt in their business practices. ${ }^{40}$ The cause of bribery is not the culture of a society, but rather the result of institutional void, which contributes mainly to China's ranking as 83 rd out of the 168 countries on the CPI. ${ }^{41}$ In addition, China was ranked the 27th of 28 world's largest economies in the Bribe Payers Index, which indicates that Chinese companies are the most likely to offer bribes when doing business abroad. ${ }^{42}$ Nevertheless, the Chinese diaspora does not exhibit similar degrees of corruption in the diverse range of countries they reside in. In the CPI 2015, Hong Kong was ranked 18th and Singapore even higher as the 8th out of 168 countries. ${ }^{43}$ According to the Ease of Doing Business Index 2015, Singapore was ranked the first, Hong Kong the third and China the 90th out of 189 countries. $^{44}$ These results are consistent with corresponding CPI rankings. It also shows that Singapore and Hong Kong are among the least corrupt cohorts, while China (83rd) is among the more corrupt in the world. A myriad of factors has driven the intensification of bribery in China, of which it is the weakness of institutions that constitutes an inherently fundamental element. The gap can be attributed to the fact that corruption is firmly rooted in China's institutional foundations, ${ }^{45}$ although it could be argued that Singapore and HK may have become less corrupt because of their colonial histories.

Even the most prudent anti-bribery provisions may not reduce corruption where bribery represents the routine ways of doing business. However, law equipped with rigorous institutions are capable of transforming culturally constructed practices. ${ }^{46}$ The three jurisdictions share similar cultural values, but there are dramatic differences between their institutions. In addition, these differences suggest that culture plays a less significant role in contributing to the CPI rankings. Guanxi is perceived as a negative activity linked inextricably with bribery practices. However, they are not necessarily directly linked. Guanxi only transitions into bribery when the exchange taking place involves corrupt intent. Whilst culture could represent an obstacle to fighting bribery, cultural pluralism is not an excuse to undermine efforts in tackling bribery extraterritorially. The Chinese economy is more robust than before, its culture has growing significant global implications and corresponding cultural values exert influence outside of China. Such repercussions will be limited when both foreign MNCs and their Chinese counterparts operate on a level playing field, which can be ensured through rule-based institutional restraint. Assuming that

\footnotetext{
39 Wan (2012).

40 Steidlmeier (1999).

41 Transparency International, Corruption Perceptions Index 2015, https://www.transparency.org/ cpi2015/\#results-table.

42 Transparency International, Bribe Payers Index Report 2011, http://www.transparency.org/bpi2011/ results.

43 Transparency International, Corruption Perceptions Index 2015, https://www.transparency.org/ cpi2015/\#results-table.

44 World Bank (2015), p 4.

45 Salbu (2000).

46 Salbu (1999).
} 
the anti-bribery institutional change is path dependent, China needs to build more effective institutions, as these have a significant influence on culture. ${ }^{47}$ At stake is the potential to ensure that the behaviour and attitudes of those in power are subject to stringent law and genuine threat of punishment when involved in bribery. Although cultural transformation takes time, institution building may act as a catalyst for changes in cultural norms. It is worth undertaking extrinsic analysis of the process of cultural change and its implications for anti-bribery regimes in the three major jurisdictions.

\section{The Catching-up of the Anti-bribery Law in China: The Amendments}

There is increasingly a global trend towards the strengthening of existing antibribery regimes. Cultural change being incremental, institutional globalisation in anti-bribery laws can minimise the negative and accentuate the positive. ${ }^{48}$ Albeit restrained by the traditions of culture, Chinese institutional development has shown growth in its sophisticated anti-bribery laws, which are not confined to domestic bribery. The law prohibits not only Chinese officials from soliciting bribes, but also the offering of bribes to government functionaries. If violated, legal entities will be subject to fines. ${ }^{49}$ Another milestone in legislation is that China has begun to catch up with its Western counterparts in criminalising bribery to foreign officials. In 2011, China took a key step, enacting legislation that criminalises paying bribes to foreign government officials for the purpose of seeking illegitimate commercial benefit. ${ }^{50}$ The intention of the Amendments is to create legislation similar to the FCPA and the UK Bribery Act. Being geopolitically constructive, Article 164 has been becoming a source of systemic risk for multinational corporations. ${ }^{51}$ The law's extraterritorial effect pressures them to take more proactive steps to prevent foreign bribery.

\subsection{The Amended Article 164 of Chinese Criminal Law (CCL 2011)}

China has adopted domestic legislation criminalising corrupt foreign business practices in line with those key multilateral treaties that set global anti-bribery standards. The Amendments in Article 164 creates a legal avenue to ensure full compliance with the OECD Convention on Combating Bribery of Foreign Public Officials in International Business Transactions (OECD Convention). With the upgrade of the provisions, China's anti-bribery law complies with comparable texts

\footnotetext{
${ }^{47}$ Schramm and Taube (2003), pp 271-296.

${ }^{48}$ Davis (2010), p 283.

49 PRC Criminal Law (中华人民共和国刑法 zhonghua renmin gongheguo xingfa) Arts. 385, 389, 391, 393.

50 The Eighth Amendment to the Criminal Law (中华人民共和国刑法修正案 (八)) was adopted by the Standing Committee of China's National People's Congress (NPC) on 25 February 2011, which came into force on 1 May 2011.

51 Gartland (2014).
} 
issued by signatory members of the OECD. ${ }^{52}$ Broadening the efforts beyond its own borders, the Amendment criminalises the providing of "money or property to any foreign party performing official duties or an official of international public organisations' for the purpose of 'seeking illegitimate business benefits'. ${ }^{53}$ Prior to this Amendment, the CCL did not have extraterritorial effect. The Amendment marks the first time in which the law addresses bribery of foreign officials. It also represents an integral part of China's effort to conform to the United Nations Convention against Corruption (UN Convention), to which China is a signatory. ${ }^{54}$ Chinese MNCs are thus pushed to abide by strict domestic laws and those abroad. Enforcement is not as robust compared to those under the FCPA and the BA 2010, explaining the shortfall in why there have been no prosecutions so far under the Amended Article 164. After all, deterrence is only achievable through credible threat. The absence of a genuine threat of criminal liability may give Chinese MNCs an advantage over their counterparts in the global marketplace.

Generally, Chinese anti-bribery laws tend to lack specificity as to the elements that constitute a violation. ${ }^{55}$ Article 164 , which contains a great deal of uncertainty, leaves much room for the exercise of discretion in enforcement. It does not carve out any affirmative defences or exceptions, such as facilitation payments under the FCPA or the 'adequate procedures defence' under the BA 2010. Justifiable as it is under the FCPA, making facilitation payment in China would still be actionable. The Chinese authorities thus have broad latitude in prosecuting potential violations. The vagueness may allow for inconsistent and at times politically motivated enforcement. ${ }^{56}$ In fact, where Chinese MNCs are already subject to the BA 2010 or the FCPA, due to their activities in the UK or their status as foreign issuers in the US given the increased cross-border transactions, there could be a scenario where the same set of facts that causes a violation of Article 164 can also constitute a violation of the FCPA and the BA 2010, and vice versa. The transnational interaction has resulted in a number of exposures initiated by FCPA investigations in the first instance. Previously, China has generally not taken action even after investigations initiated by other countries with respect to bribery in China have been disclosed. It is argued that the Eighth Amendment is rather more of symbolic importance, since the new provision fails to encompass the full range of conduct intended to trigger criminal liability under the UN Convention against Corruption Article 16. It is, however, a significant step in its gradual approach to fighting transnational bribery. The Amendment empowers the Chinese authorities to exercise greater vigilance in monitoring the overseas activities of China's MNCs. It is still at an early stage, but reflective of China's intention to apply the Amendment against foreign bribery.

\footnotetext{
52 OECD, Convention on Combating Bribery of Foreign Public Officials in International Business Transactions 2011, http://www.oecd.org/daf/anti-bribery/ConvCombatBribery_ENG.pdf.

53 CCL 2011 Art. 164(2); the 8th Amendment took effect on 1 May 2011.

54 China signed the UN Convention on 10 December 2003 and ratified it on 13 January 2006, https:// www.unodc.org/unodc/en/treaties/CAC/signatories.html.

55 Wombolt and Galvin (2012).

56 'Strong Arm of the Law: China's Commercial Corruption Laws Are Undermined by Politically Driven Enforcement', China Economic Review (13 July 2012).
} 
Furthermore, the provision's expanded scope is significant in light of the increasingly aggressive application of extraterritorial jurisdiction over bribery under the FCPA and the BA 2010. In consequence, compliance with the two antibribery laws does not necessarily ensure compliance with the provision under CCL 2011. This complicates MNCs' efforts to structure their compliance, in a way that does not violate Chinese anti-bribery laws. The multinationals must take this uncertainty into account when determining the level of litigation risk posed by the Amendment. As such, the Eighth Amendment should, in principle, improve Chinese MNCs' ethical standards and help to level the playing field in overseas markets.

\subsection{The Ninth Amendment to the Chinese Criminal Law (CCL 2015)}

In order to justify its legitimacy in power, the Chinese government is increasingly determined to change the long-standing culture of graft and backhanders. The Ninth Amendment to the PRC Criminal Law came into effect on 1 November $2015 .^{57}$ Previous legal regimes generally targeted only officials who accept bribes. ${ }^{58}$ The Ninth Amendment revised several anti-bribery provisions, mainly to impose harsher punishment on offenders who provide bribes. This approach reinforces and broadens the scope of compliance with the UN Convention against Corruption. ${ }^{59}$ In particular, the Ninth Amendment echoes Article 21 of the UN Convention, which covers both active and passive bribery. It imposes additional grounds of liability as well as harsher penalties for bribery offences, which represents China's escalating effort in fighting bribery. The Amendment differs from the FCPA in that the latter aspires to "concentrate on the supply side by targeting the MNCs that offer bribes to government officials'. 60

The criminal threshold was set at ¥RMB 200,000 (£20,000) where a bribe is paid by entities. ${ }^{61}$ However, an accurate interpretation to certain criteria remains overwhelmingly challenging in judges' discretion. Among other things, these include how to apply punishment based on criteria such as 'serious circumstances', 'extremely serious circumstances' and 'significant loss of national interests' as outlined in the Ninth Amendment. Noteworthy is a judicial interpretation for the Handling of Criminal Cases of Embezzlement and Bribery in $2016 .{ }^{62}$ The legallybinding decree not only clarifies thresholds, but also specifies what it means in

\footnotetext{
57 The National People's Congress of China promulgated the 9th Amendment to the Criminal Law (中华 人民共和国刑法修正案 (九)) on 29 August 2015.

58 The FCPA does not provide a mechanism to prosecute foreign officials for receiving bribes, presumably for reasons of international comity. Unlike the FCPA, the Bribery Act criminalizes the receipt of bribes, in addition to the payment of bribes.

59 UN Convention covers 'Bribery of national public officials (Article 1)'; Bribery of foreign public officials and officials of public international organisations (Art. 16); and Bribery in the private sector (Art. 21).

60 Warin et al. (2010a), p 41.

61 CCL Art. 393.

62 The judicial interpretation (最高人民法院、最高人民检察院关于办理贪污贿赂刑事案件适用法律 若干问题的解释) was jointly issued by the Supreme People's Court and the Supreme People's Procuratorate on 18 April 2016.
} 
judicial practice. Furthermore, it adds a new provision to Article 390, targeting those giving bribes to a person who may exert influence on a current or former government official. The Chinese Criminal Procedure Law defines 'close relatives' as 'husband, wife, father, mother, son, daughter, and siblings'. ${ }^{63}$ there is no guidance in the Amendment as to who will qualify as a person 'closely related' to the state functionary. A lack of definition may give the authorities broader discretion and flexibility in prosecuting a bribe-giver. ${ }^{64}$ Such 'influential persons' include anyone who is closely associated with a current or former government official. ${ }^{65}$ This Amendment mirrors the approach in US v. Liebo, where it was found to be illegal to corruptly influence a foreign official indirectly. ${ }^{66}$ It represents a further effort to prevent government officials from receiving bribes through their inner circle, regardless of whether it happens during their government service or ex post. ${ }^{67}$ Corporate compliance due diligence should broaden payee background checks to 'red flag' not only current and former government officials, but also any of their close associates to prevent such a delicate violation. The provision tries to resolve an inherent problem in the practice where bribers were penalised far less harshly than were the bribees. This disparity was based on an assumption that the former is often a reluctant participant in bribery. However, bribers and bribees are often interdependent on each other.

Finally, a Joint Interpretation provides potential credit for self-disclosure or otherwise confessing wrongdoing in respect of the policy of leniency. ${ }^{68}$ Under the Ninth CCL Amendment (CCL 2015), an offender who self-reports before the commencement of a prosecution will only be eligible for an exemption of punishment under particular circumstances. For instance, the offense was relatively minor or the accused has provided information to authorities leading to the 'successful investigation of a major case'. ${ }^{69}$ Other than these special circumstances, the criminal penalties to be imposed on offenders who self-disclose will only be mitigated but not eliminated. ${ }^{70}$ The Ninth Amendment substantially limits the circumstances under which a confessing bribe offeror may be exempted from criminal liability. Tightening the restrictions on immunity represents a major shift

\footnotetext{
63 Criminal Procedure Law 2012 (中华人民共和国刑事诉讼法 zhonghua renmin gongheguo xingshi susongfa) Art. 106 (6).

64 Tan and Wang (2015).

65 CCL 2015 Art. 46.

66 United States v. Liebo, 923 F.2d 1308, 1311 (8th Cir. 1991); FCPA Guidance, p 16.

67 The Ninth Amendment of CCL 2015 Art. 390.

68 China's Supreme People's Court (SPC) and Supreme People's Procuratorate (SPP) issued a Joint Interpretation to apply anti-bribery laws on 26 December 2012. Interpretation of the Supreme People's Court and the Supreme People's Procuratorate of Several Issues Concerning the Application of Law for Handling Criminal Cases of Bribery 最高人民法院、最高人民检察院关于办理行贿刑事案件具体应 用法律若干问题的解释 (SPC and SPP Joint Judicial Interpretation). The Joint Interpretation was adopted at the 1547th Meeting of the Judicial Committee of the Supreme People's Court on 14 May 2012 and the 77th meeting of the 11th Procuratorial Committee of the Supreme People's Procuratorate on 21 August 2012. It took effect on 1 January 2013. Matthews (2013). SPC and SPP Joint Judicial Interpretation Arts. 7-9.

69 CCL 2015 Art. 45.

${ }^{70}$ CCL 2015 Art. 45.
} 
from the pre-Amendment legal precept that imposes harsher punishments on bribereceivers while offering leniency to bribe-givers with the intent to elicit the cooperation. $^{71}$ This change means increased risks to MNCs, as once a bribery case is escalated to criminal prosecution, it will be unlikely for the firm to escape criminal penalties. At this initial stage of the anti-bribery transformation, it all comes down to the key point of how China can devote substantial resources to ensure that the Amendments are effectively enforced.

\subsection{The Impact on MNCs' Global Compliance Strategies}

China's anti-corruption landscape has become more stringent than ever with the above Amendments. The approaches bring China's statutory enforcement authority standards to levels among the world's toughest anti-bribery laws, which stand aloof from the traditional Chinese culture of gift-giving. The updating of the Chinese Criminal Law represents a positive step, given China's growing role in the global market. The global anti-bribery regimes have thus been reinforced with China moving forward on the recent Amendments. Enforcement of China's new law would send a strong message that China is assuming a position of global leadership consistent with both its commitment to rule of law and its stature as the second largest economy in the world. Given the general lack of affirmative defences or exceptions, the Amendments seek to impose harsher penalties than those under the FCPA and the BA 2010, which target mainly on the supply side of the bribery. As such, MNCs should proactively review and ensure that their due diligence and stringent compliance programmes rise to this new challenge. They need to reassess their existing internal control procedures to ensure even their subsidiaries are protected adequately. Both the FCPA and the BA 2010 require those MNCs to be relatively certain that no bribery is taking place with Chinese subsidiaries and their supply chains. MNCs subject to investigations by UK or US regulators should operate conforming to global resolutions, including those created by Chinese antibribery authorities.

Plausibly, it still remains unclear whether the stringent Amendments could meaningfully change the scenario between the anti-bribery institutions and the longstanding culture with particular regard to gift-giving. The Eighth Amendment provides a macro framework outlawing bribery of foreign officials, while the Ninth one on a more micro level entails constructive constraints on the briber who likely gives in the name of gift-giving. It is essential to ascertain the extent to which the divergent statutory approaches by the three jurisdictions respectively impose on the intersection of culture and anti-bribery endeavours. More specifically, it is argued that gift-giving and guanxi-building are not unique in China, while the institution matters via the anti-bribery law in terms of the essence of these universal social phenomena. Some specific provisions under the FCPA and the BA 2010 provide delicate leverage in response to the hypothesis.

71 Tan and Wang (2015). 


\section{Are Anti-Bribery Watered Down under the FCPA and the BA 2010?}

It is vital to be aware of the legal scenarios of the gift-giving and hospitality culture between major jurisdictions, as they are at stake in achieving the globalisation of anti-bribery law on the one hand, and facilitating MNCs' global compliance on the other. In theory, any gift or hospitality will potentially trigger liability, where it is provided with the intention of inducing the recipient to act improperly. The UK Bribery Act 2010 creates a tougher framework for prosecution than applies under the FCPA. It remains to be seen whether the recent Guidance undermines the global efforts to tackle bribery, or makes the implementation slide into more commonsense practices.

\subsection{The Controversial Exception of Facilitation Payments and Hospitality}

The Security Exchange Commission (SEC) and Department of Justice (DoJ) rely on a broad interpretation of 'anything of value' when justifying the criminalization of a variety of corporate hospitality and gift-giving customs. ${ }^{72}$ Certain expenses can be considered as affirmative defence for the sake of promoting business. ${ }^{73}$ While illegal under the BA 2010, the facilitation payment remains lawful under the FCPA. ${ }^{74}$ An exception provision permits payment to foreign officials to expedite securing the performance of a routine governmental action. ${ }^{75}$ It is not seen as a pragmatic solution labelled with bribery. Small payments made to expedite a foreign official's routine service are often seen as a more efficient solution, or a necessary evil within a society where such actions are a common lubricant. ${ }^{76}$ There is no universally accepted definition of what constitutes a permissible facilitation payment. Like the interplay between guanxi and bribery, the line is often blurred between an illegal bribe and a facilitation payment. The court decides how the exception provision is interpreted in particular circumstances, where the foreign official does not exercise any discretion. Whilst payments of such kind may drive the officials to expedite their duties, the payments per se are corrosive in nature. ${ }^{77}$ The recipient junior official may not have a final decision, which roles still constitute an integral part of the decision-making process. As Transparency International observed:

Paying small bribes feeds a culture of corruption which creates an unstable operating environment for companies. They should be seen as a

\footnotetext{
72 The Securities and Exchange Commission, Litigation Release No. 21770, 10 December 2010. Securities and Exchange Commission v. RAE Systems Inc. Civil Action No. 1:10-cv-02093 (D.D.C., December 10, 2010).

7315 USC $\S \S 78 \mathrm{dd}-1$ (c) (2), 78dd-2(c) (2).

${ }^{74}$ Windsor and Getz (2000), p 748.

7515 USC $\S \S 78 d d-1(b)$ and (f)(3); Securities and Exchange Act of 1934 s. 30A.

${ }^{76}$ Carling, Paasche and Siegel (2015).

77 OECD, Recommendation of the Council for Further Combating Bribery of Foreign Public Officials in International Business Transactions (26 November 2009) Art. 6, http://www.oecd.org/daf/anti-bribery/ ConvCombatBribery_ENG.pdf.
} 
part of a cycle of bribery that corrodes public and business standards and provides a climate for much larger public sector bribery. ${ }^{78}$

Hospitality must be bona fide and transparent for the sake of enhancing safeguarding procedures. In practice, the frontier is uncertain between a bona fide business expenditure and a bribe. Although it is said that a lavish one could trigger FCPA liability, the difficulty is to distinguish when hospitality is seen as an improper inducement to seek business. Furthermore, it should never be seen as a viable safe harbour when used for foreign MNCs to build guanxi in China, since it has always been narrowly construed. ${ }^{79}$ Neither Chinese culture nor anti-bribery law yields explicit solutions to this controversy. The facilitation payment is not only in contrast to the BA 2010 under which it is forbidden, but also inconsistent with the OECD Convention. ${ }^{80}$ In order to level the playing field, facilitation payments should be abolished.

\subsection{The Ministry of Justice Guideline of Bribery Act 2010}

The UK Bribery Act (BA 2010) prohibits bribery of a foreign public official in order to secure an advantage in the conduct of business. ${ }^{81}$ However, Guidance issued by the UK Ministry of Justice complicates compliance efforts and leads to inconsistency in discharging the policies of legitimate business expenses. ${ }^{82} \mathrm{~A}$ nonsystematic payment would not necessarily be illegal. ${ }^{83}$ Some contextual considerations resolve around the varying cultural settings under which certain payments, such as gift-giving, may not constitute bribery. The existence of corrupt intent then rests within several factors, such as the nature, value and transparency of the deal.

\subsubsection{The World's 'Toughest' Anti-bribery Law?}

The Bribery Act 2010 is tougher and broader in scope than the FCPA. A firm can be prosecuted for failing to prevent bribery regardless of the knowledge or intent of its management. Corporations face unlimited fines for violations of the Act. ${ }^{84}$ Previously, senior executives were considered to be the directing mind and controlling will of a company for the purposes of establishing an offence. ${ }^{85}$ The BA 2010 creates a new strict liability offense for failing to take preventative steps

\footnotetext{
78 Transparency International, Countering Small Bribes (June 2014), http://www.transparency.org.uk/ publications/countering-small-bribes/.

79 Warin et al. (2010a), p 63.

${ }^{80}$ UK Ministry of Justice, The Bribery Act 2010 Guidance $\S$ 44-47, http://www.justice.gov.uk/ downloads/legislation/bribery-act-2010-guidance.pdf, p 18 ('Bribery Act 2010 Guidance').

81 BA 2010 s. 6.

82 BA 2010 s. 9(1): the UK Ministry of Justice published a guidance on 14 September 2010 required by the provision.

83 FCPA Guidance, p 15.

${ }^{84}$ BA 2010 s. 11.

85 Yarosky (1964).
} 
against bribery, subject to a defence of adequate procedures ${ }^{86}$ This provision renders the prosecution of corporations easier and avoids the prosecutorial pitfalls of the directing mind doctrine. The statute also applies extraterritorially to any company with links to the UK, irrespective of where the crime occurs. ${ }^{87}$ Provided that a Chinese MNC carries on a business or part of a business in British territories, the UK courts can exercise jurisdiction. ${ }^{88}$ With the advent of the BA 2010 and its extraterritorial reach, it is important for foreign MNCs entering the Chinese market to bear these cultural traits in mind when rolling out an anti-bribery compliance programme. The 'adequate procedures' can be deployed as the only affirmative defence, that is, the defendant can show that they had adequate anti-bribery compliance procedures in place. ${ }^{89}$

\subsubsection{The Inconsistency under the Bribery Act 2010 Guidance}

Bribes are often disguised as legitimate business expenditure. ${ }^{90}$ Although a reasonable gift or hospitality is unlikely to be penalised, it is difficult to explicitly quantify, given the blurred line between a legitimate expenditure and an unlawful bribe. The Guidance to the BA 2010 creates loopholes for bribery to go unchecked, stating that:

[p]roviding flights, accommodation and reasonable hospitality for a foreign official and their spouse to visit New York to meet senior UK executives would be unlikely to breach the law. ${ }^{91}$

It indicates that the Bribery Act 2010 should be implemented in a common sense manner. ${ }^{92}$ The Serious Fraud Office (SFO) seems to take a proportionate approach and would only prosecute where there was evidence of systematic bribery rather than a one-off payment. ${ }^{93}$ The burden of proof, however, remains with the company. Rational as it appears, enforcement agencies have been conferred broad discretion to interpret the line under which some grease payments are actionable. The Guidance creates significant exemptions that directly contradict the spirit of the Bribery Act. ${ }^{94}$ The exemptions create artificial distinctions that are

\footnotetext{
86 BA 2010 s. 7.

87 BA 2010 s. 12(5).

88 BA 2010 s. 7.

89 BA 2010 s. 7(2).

90 Serious Fraud Office (SFO) (2012).

91 Bribery Act 2010 Guidance $\S 31$, p 14.

92 Bribery Act 2010 Guidance $\S 36$.

93 Bond Anti-Corruption Group submission to the Cabinet Office Enforcement Review on the Guidance to the Bribery Act (30 July 2015), http://www.cw-uk.org/wp-content/uploads/2015/09/BOND-AntiCorruption-Group-submission-on-Bribery-Act-Guidance-Review-July-2015.pdf.

94 UK Parliament HC 847 International Development Committee, 'Written Evidence from Christian Aid' (27 April 2011), http://www.publications.parliament.uk/pa/cm201012/cmselect/cmintdev/847/847vw06. htm.
} 
difficult to enforce, undermine corporate anti-bribery procedures, confuse antibribery communication with employees and other associated persons, and perpetuate an existing 'culture' of bribery and have the potential to be abused. $^{95}$

The Guidance even provides that companies that only indirectly benefit from bribery are unlikely to be held culpable. ${ }^{96}$ It is worrying that the Guidance would allow MNCs to escape liability by outsourcing bribery to subsidiaries or subcontractors. ${ }^{97}$

\subsection{Soften the Anti-Bribery Efforts}

It remains unclear whether there are substantive differences between Western facilitation payments and the prevalent gift-giving practice in China. The latter is readily seen as a catalyst of bribery in China, while the former is lawful under the FCPA, though unlawful under the BA 2010. Guanxi is widely perceived by the West as a sordid form of favouritism and nepotism. ${ }^{98}$ According to the Guidance/ Guidelines to the two major anti-bribery laws, certain business expenditures, like reasonable hospitality are not considered bribery. To understand the rationale behind the delicate distinction may help MNCs be alert to potential pitfalls across jurisdictions.

\subsubsection{A Classical Preposition: The Chinese Guanxi Vis-à-Vis The Western Network}

Gift-giving manifests, to some degree, favours that are not uniquely a Chinese phenomenon. Pervasive corruption reinforces a negative perception of guanxi. With corruption being endemic in China, gift-giving is not to blame since it represents only part of the wider landscape of guanxi. There is little difference between guanxi and Western networking practices. Guanxi is hard to interpret precisely. Favours can be regarded as the ultimate carrier of guanxi, which are typically of a more personal nature than those performed in Western networking. ${ }^{99}$ As a means of expressing respect and honour, gift giving shows that a relationship is valued. It expresses good will and gratitude, which is considered a dynamic form of social contracting. ${ }^{100}$ The concept of guanxi overlaps, to a large degree, with the Western concept of networking. For this reason, it is not justified to differentiate these two social phenomena extensively. As stated in the Guide to the FCPA, giving a small gift is an appropriate way for business people to display respect for each other. ${ }^{101}$

\footnotetext{
95 Bribery Act 2010 Guidance $\S 45$, p 19.

96 Bribery Act 2010 Guidance $\$ \S 40-42$.

97 UK Parliament HC 847 International Development Committee, 'Written Evidence from Tearfund and CAFOD' (27 April 2011), http://www.publications.parliament.uk/pa/cm201012/cmselect/cmintdev/847/ 847vw10.htm; Bribery Act 2010 Guidance $§ 39$.

98 Yeung and Tung (1996).

99 Michailova and Worm (2003), p 510.

100 OECD (1998), p 8.

101 FCPA Guidance, p 15.
} 
Similarly, the FCPA does not prohibit gift-giving, but only illegitimate bribes disguised as a gift. ${ }^{102}$ By means of reduction to absurdity, one of the Transparency International comments indirectly proves the negligible difference between the two, proposing that: 'small companies are far more vulnerable to corruption since they often do not have the connections to bypass individual officials' ${ }^{103}$

Typically, an individual offers a gift in their guanxi network for an indefinite return, whilst their Western counterparts expect a prompt return following the facilitation payment. The latter is, in substance, not a guanxi-related giving, but targets particularly the recipient's routine performance. The use of facilitation payments is one of the methods to build a pragmatic and instant guanxi. Some commentators have echoed such a discourse, stating that: 'the US society has a tradition which pursues specificity and decisiveness'. ${ }^{104}$ Both guanxi and Western networking share similar underlying cultural implications of a moral and ethical indebtedness. Some differences manifest themselves in more psychological rather than substantive perspectives. From a legal perspective, the only plausible difference appears to be that the gift-giving in the West has been sophisticatedly institutionalised. Guanxi stands as an informal antagonistic relationship to the formal Western system of legal rights. ${ }^{105}$ In the West, some pre-existing institutions produce relatively clear jurisdictional lines. As such, a prerequisite to establish criminal liability rests with a sufficient causal link between the advantage/bribe and the intention to influence, ${ }^{106}$ whereas within a guanxi network, the influence could take shape long after the gift-giving. Chinese institutions, to some extent, do not reside in jurisdictions, but within relationships. Although gift-giving is explicitly regulated even in Chinese codified law, it has never been robustly enforced. This contradiction promotes the perception that gift-giving constitutes a part of the Chinese culture uniquely, or at least, it differs substantively from that in the West.

\subsubsection{Global Anti-Bribery Efforts Diluted Under the Guidance}

The Guidance to BA 2010 creates a new venue through which MNCs are virtually not prohibited from making facilitation payments, provided they are proved to be made reasonably and proportionately. ${ }^{107}$ Multinationals may now have, in substance, a new defence to Sect. 7 offence apart from the classical one of 'adequate procedures'. ${ }^{108}$ The de facto defence of 'reasonable and proportionate hospitality' along with the de jure defence of 'adequate procedures' are equivalent to certain FCPA's provisions. Neither the BA 2010 nor the FCPA set thresholds for expenses in gifts and hospitality. The BA 2010 expects companies to adopt a 'zero

\footnotetext{
102 FCPA Guidance, $\mathrm{p} 16$.

103 'When a Bribe is Merely Facilitating Business', The Economist (1 June 2011).

104 Lin and Malhotra (2012), p 121.

105 Hamilton (1994).

106 Bribery Act 2010 Guidance $\S 28$, p 13 .

107 Torres-Fowler and Anderson (2011).

108 BA 2010 s. 7(2); the only defence available under BA 2010 is to demonstrate that the company had 'adequate procedures' designed to prevent persons associated with it from undertaking bribery.
} 
tolerance' policy towards such expenditures. ${ }^{109}$ The Guidance provides high-risk examples of acceptable hospitality. These approaches demonstrate an attempt to soften the BA 2010s position on some tough tenets. On the other hand, the Guidance does not have the force of law. It helps explain what kind of procedures it regards as likely to be adequate under Sect. 7. Ultimately it will be for the courts to exercise its discretion. In this regard, it remains to be seen whether Guidance will alter the future prosecution landscape. In respect to rapidly changing global regulations and needs, a well advised policy for MNCs is to adopt a no-bribes policy and rigorously enforce it throughout their global operations. A corporate culture with a commitment to integrity providing 'tone-from-the-top' is also critical to implementing a programme to counter potentially liable practices, such as gift-giving and hospitality expenditure.

\section{A Pseudo-proposition: The Argument of an Unlevelled Playing Field}

The international community has endeavoured to create a level playing field in order to combat bribery beyond their own territories. Despite a growing number of FCPA prosecutions against foreign MNCs, it is perceived that the Chinese MNCs are not subject to similar stringent anti-bribery laws. Chinese firms may not have to bear the costs of additional due diligence and scrutiny under the FCPA or the BA 2010. With increasing convergence of the global anti-bribery regimes, uneven law enforcement will undercut the aim of the OECD Convention to harmonise international antibribery standards. This may plausibly harm those in high-enforcement nations. Paradoxically, the unlevelled playing field may create a systematic risk that could prevent those Western MNCs from securing businesses while competing with their Chinese counterparts. It is however, noteworthy that both US and UK authorities have increased their prosecution of foreign entities. A long-standing debate centres on whether the BA 2010 and the FCPA genuinely place British and American businesses at a real disadvantage.

\subsection{Are American and British Corporations Genuinely Disadvantaged?}

Would the FCPA and the BA 2010 enforcement counterproductively chill business by discouraging corporate entry into the Chinese market? Arguably, widespread corruption in China could put foreign MNCs between the proverbial rock and a hard place. ${ }^{110}$ The statutes are conceived to make Western MNCs less competitive due to the uneven enforcement of law. Hypothetically, the foreign MNCs then incur a competitive disadvantage against their counterparts in China, where anti-bribery laws are not enforced as rigorously as in the US and the UK. ${ }^{11}$ The resultant asymmetrical market opportunities limit the ability of foreign MNCs to compete in China. Nevertheless, some statistics provide empirical evidence to the contrary.

\footnotetext{
109 Warin et al. (2010b), p 21.

110 Norton (2006), p 22.

111 Pedersen (2008).
} 


\subsubsection{Empirical Evidence}

The MNC's home state laws cannot completely reach transnational bribery, and the host state's legal framework is therefore required for effective control. ${ }^{112}$ In 2011 , $72 \%$ of the financial penalties in FCPA cases were assessed by US authorities against non-US companies, even though these companies comprised only $41 \%$ of those investigated. ${ }^{113}$ From 2009 to 2011, 16 of the 36 FCPA enforcement cases have involved non-US parent companies. ${ }^{114}$ Nine of the ten largest penalties until 2011 imposed by US authorities for alleged FCPA violations were levied against foreign companies. ${ }^{115}$ Several of the most high-profile FCPA enforcement actions of all-time have been against foreign companies, too. Further research puts forward that $90 \%$ of small-and-medium enterprises (SMEs) have had no problems with the provisions of the UK Bribery Act 2010 and 89\% of SMEs felt that the BA 2010 had no impact on their ability to export. ${ }^{116}$ In reality, China-based MNCs are faced with a rapidly evolving domestic anti-bribery compliance environment. They are not exempt from the FCPA's and the BA 2010's reach either. For instance, the FCPA accounting provisions, require corporations to

(i) make and keep books and records that accurately and fairly reflect the transactions of the corporation; and

(ii) devise and maintain an adequate system of internal accounting controls. ${ }^{117}$

Chinese MNCs are jumping to take advantage of the deep capital markets provided by Western exchanges. Simultaneously, they have been running into the challenges of complying with the FCPA and the Bribery Act 2010 as well. As some commentators revealed: "nearly one-half of all China-related corporate prosecutions under the FCPA since 2002 involved the provision of gifts.' 118

\subsubsection{An Invalidated Pseudo-Proposition}

Non sequitur invalidates the above-mentioned argument that the US and UK corporations are being disadvantaged. Firstly, China has accelerated criminalisation of paying bribes to foreign officials, mirroring the exterritorial restrictions provided under both the BA 2010 and the FCPA. Those internationally accepted norms have been reflected in China's amended Article 164. Foreign MNCs are to be treated the

\footnotetext{
112 Nichols (1999c), p 259; Nichols (1999b).

113 US Department of Justice, Related Enforcement Actions, Chronological List 2011, http://www.justice. gov/criminal/fraud/fcpa/cases/2011.html.

114 Ibid.

115 Ibid.

116 HM Government, Insight into Awareness and Impact of the Bribery Act 2010-Among Small and Medium Sized Enterprises (SMEs) (2015), pp 37, 38, https://www.gov.uk/government/uploads/system/ uploads/attachment_data/file/440661/insight-into-awareness-and-impact-of-the-bribery-act-2010.pdf (accessed 1 September 2017).

11715 USC $\$ 78 \mathrm{~m}$.

118 Warin et al. (2010a), p 59.
} 
same as their Chinese counterparts, at least, on paper. Secondly, it is perceived that the UK and US multinationals have been penalised out of either protectionism, nationalism or selective enforcement. Without solid evidence, such a perception is only to be viewed as a pseudo-proposition. Lastly, the empirical data mentioned above proves to be counterintuitive. The fact casts doubt on the tenability of the arguments, since overwhelmingly more foreign companies than US firms have been investigated and prosecuted under the FCPA. The anti-bribery efforts have been taking place in both international as well as domestic fora, ${ }^{119}$ although the effectiveness of extraterritorial restrictions on bribery remains to be seen. In order to create a level playing field, global anti-bribery initiatives have been emerging toward the development of an avenue to deter transnational bribery. Under the UN and OECD Conventions, the signatory countries are committed to outlawing extraterritorial bribes throughout the world.

\subsection{International Soft Law in Combating Global Bribery}

Extrinsic pressure is imperative to ensure efficacy of a domestic anti-bribery regime. There is great potential to reduce bribery with external oversight and transparency. The Securities Exchange Commission (SEC) and the Department of Justice (DoJ) have been seeking to ensure a levelling of the playing field via international avenues of soft law. The United Nations adopted the Convention against Corruption (UN Convention) in $2003,{ }^{120}$ which requires signatory parties to criminalise bribery of both national and foreign public officials. ${ }^{121}$ The OECD Convention Represents another noteworthy international development, and each signatory nation is pledged to criminalise foreign bribery. ${ }^{122}$ It calls on treaty parties to enact legislation making it a criminal offense to offer bribes to foreign officials 'in order to obtain or retain business or other improper advantages in the conduct of international business'. ${ }^{123}$ The two soft law initiatives pave the way to be the foremost global legal instruments to fight foreign bribery. ${ }^{124}$ Like the FCPA, and China's approach under the previous CCL, the OECD Convention covers only the active bribery, i.e. the liability of bribers, excluding the passive bribery. ${ }^{125}$ The two Conventions have prompted members to accept international anti-bribery norms and to move toward adopting norms into their domestic law. The heightened regulatory scrutiny and enforcement are accordingly evolving into criminalisation of corporate bribery. China's accession to the Conventions have dramatically reinforced the integration of its domestic institutions into the global anti-bribery regimes. The soft law helps to

\footnotetext{
119 Deming (1999).

120 The UN Convention approved by the Ad Hoc Committee was adopted by the General Assembly by resolution 58/4 of 31 October 2003, and came into effect in December 2005.

121 The UN Convention against Corruption Arts. 15-16.

122 Convention on Combating Bribery of Foreign Public Officials in International Business Transactions, 18 December 1997, 37 ILM 1.

123 OECD Convention Art. 1.1.

124 OECD (2008), p 3.

125 Ibid., at p 12.
} 
undermine MNCs' claims to cultural sensitivity, but these effects can only complement, not substitute domestic anti-bribery law. ${ }^{126}$

\section{Plausible Cultural Variables Vis-à-Vis Globalised Anti-Bribery Compliance}

Chinese culture influences the way people think, act and hence the extent to which they should be held responsible for their behaviour. As a double-edged sword, the culture per se can contribute to illegal behaviour like bribery, while it can also be a vehicle for promoting good ethical conduct. ${ }^{127}$ As transactions cross borders, simultaneously satisfying each of the overlapping anti-bribery laws of multiple jurisdictions can be challenging. It is never enough to stress the need for a culture of compliance. This section explores how to tackle bribery through taking preventive measures and fostering a culture of integrity.

\subsection{Make Gift-Giving Policies Jurisdiction Specific}

Conventional wisdom holds that foreign MNCs' success in China depends to a certain degree of adapting to Chinese cultural values, while their compliance regimes tend to reflect the parent companies' corporate culture and strategic imperatives. ${ }^{128}$ One of the primary risks that China's culture pose to MNCs is that they could run afoul of the FCPA or the UK Bribery Act. Foreign MNCs may attempt to defend their bribery in reference to China's traditions of gift giving. The claim that bribery exists intrinsically in China's culture remains a plausible pseudo proposition, which misleads the MNCs' global anti-bribery efforts.

Extraterritoriality arguably disregards the values of other cultures, given that gift policies vary considerably from jurisdiction to jurisdiction. ${ }^{129}$ What might well constitute a reasonable gift in China may violate anti-bribery laws in other jurisdictions. The BA 2010 provides that: 'any local custom or practice is to be disregarded unless it is permitted or required by the written law applicable to the country or territory concerned.' ${ }^{130}$ Law transforms a culture that tolerates corruption, while simultaneously the culture triggers a response of enacting more anti-bribery laws. In this sense, the law is not merely a reflection or by-product of culture, but can also serve a legitimate constitutive role in forming culture. ${ }^{131}$ With more anti-bribery laws with extraterritorial effect, the room for customary giftgiving practices is shrinking, even though they do not truly constitute bribery. ${ }^{132}$ Neither Article 164, the FCPA nor the Bribery Act 2010 grants a culture defence, so

\footnotetext{
126 Rose (2015), pp 15-27.

127 Donaldson (1996).

128 Yang (1999), p 16.

129 Windsor and Getz (2000).

130 BA 2010 s. 5.

131 Mautner (2011); Nichols (1997), p 1271.

132 Fort and Noone (2000).
} 
it is a challenge for MNCs to ensure that they are upholding the law. ${ }^{133}$ As such, the Chinese cultural effect should not be read too widely with the amended Article 164 integrated into the global anti-bribery regime. MNCs should display subcultures and countercultures in their various overseas operations, instead of behaving in a way 'when in Rome do as the Romans'.

The concept of guanxi is central to Chinese society and thus heavily influences corporate behaviour. It is a misconception that a corporate culture of corruption exists in which bribery is an integral part of doing business. Foreign MNCs are thus expected to focus increasingly on strengthening their anti-bribery compliance programmes in China, simply because they are forbidden to pay bribes in both China and their home states. Foreign MNCs must prohibit bribery despite local custom. ${ }^{134}$ The Chinese culture of gift-giving does not justify that Western MNCs should follow the Chinese way to secure business opportunities. Bribery is normally disguised in traditional guanxi practices and facilitated by MNCs' local subsidiaries. A cultural sensitivity card is sometimes played by foreign MNCs, although it is often driven by profit motives. ${ }^{135}$ However, invoking culture as a justification for making bribes can by no means, be considered as a defence if prosecuted. The MNCs should in all circumstances respect the value of free market, but not use China's culture as an excuse for committing bribery. ${ }^{136}$ There is substantial convergence on values about bribery across various cultures. As discussed in previous sections, condemnation of bribery is a value shared by Confucianism. Bribery is never justified as a paradoxical reflection of cultural norms. Otherwise, such plausible sophistry will compromise efforts to produce justice and integrity. ${ }^{137}$

\subsection{The Functional Transformation: A Path-Dependency Resolution}

Instances of corruption are at their highest in China where there is a profound economic or political transformation under way, during which culture does not play a decisive role. ${ }^{138}$ It is weak governance that engenders bribery in the transition from a planned to a market-orientated economy. With corruption spreading into every corner of society, social and political stability has been threatened. ${ }^{139}$ Some Chinese government officials prevalently engage in self-interested corruption and take advantage of their positions to engage in rent-seeking and solicit MNCs for bribes. This undermines the state's claim to legitimacy. ${ }^{140}$ A number of social, economic and institutional factors contribute to bribery, of which undeveloped rule of law and lack of transparency increase the risk. Accordingly, anti-bribery efforts

\footnotetext{
133 Vega (2009).

134 Stevenson and Wagoner (2011), p 788.

135 Ashe (2005).

136 Rose-Ackerman (2010).

137 Bribery Act 2010 Guidance $§ 45$.

138 Montigny (2015).

139 Johnston and Hao (1995).

140 Rose-Ackerman (2010).
} 
toward a more transparent and competitive market are one of the key priorities in China.

\subsubsection{The Deep Causes}

The rule of law and the market economy have not been fully-fledged in China's transition to a market economy. ${ }^{141}$ First of all, underlying corruption is a growing tension between the transitional socialist economy and the Chinese traditional values, which the current unestablished political and institutional frameworks have failed to handle. ${ }^{142}$ As Perry noted: 'advanced economic development may indeed demand new political arrangements that afford far greater autonomy to legal institutions and civil society. ${ }^{143}$ Secondly, endemic corruption emerges in the times of economic or political flux because of a non-democratic process. ${ }^{144}$ Lord Acton observed that: "power tends to corrupt and absolute power corrupts absolutely.' ${ }^{145}$ In the absence of adequate internal control and external oversight pressure, the pervasive governmental involvement in China's transitional economy precipitates prevalent corruption. Insufficient governance leaves the system open to abuse, which renders it possible that bribery tends to corrupt the very administrative systems that are asked to regulate bribery. Finally, China's export-led growth masks the macroeconomic costs of corruption. Due to the excessive state intervention and defective enforcement of anti-bribery laws, the Chinese economic reform has led to ingrained corruption of the political system. ${ }^{146}$ The blurred lines between the public and private spheres provide incentives for rent-seeking and increase susceptibility to bribery, which creeps in primarily due to a culture of discretionary decision making by public officials.

\subsubsection{A Path-Dependency Resolution}

Corruption in China is intensifying and institutionalising. ${ }^{147}$ It is not necessarily true that the fewer resources a government controls, the fewer the opportunities there are for corruption. ${ }^{148}$ It simply reduces the intrusiveness of governments that makes bribery less rewarding. If bribery is the result of institutional failures, it will likely reappear as one group of malefactors is replaced with another. ${ }^{149}$ The emerging Chinese anti-bribery regime necessitates increased integration into global systems in

\footnotetext{
141 Schipani et al. (2016).

142 Richardson and Tepikina (2014).

143 Perry (2007).

144 Montigny (2015).

145 Lord Acton, 'Letter to Bishop Mandell Creighton, 5 April 1887', in: J. N. Figgis and R. V. Laurence (eds.), Historical Essays and Studies (London, Macmillan 1907).

146 Lieberthal (1996).

147 Wedeman (2005), p 920.

148 Chafuen and Guzman (2000), p 51.

149 Rose-Ackerman (2010).
} 
terms of not only law on paper but also complementary institution building. ${ }^{150}$ The current anti-bribery approaches address the symptoms of bribery without tackling the root causes. Unless there are reforms that establish the rule of law, this approach only creates an opportunity for someone else to step in and take advantage of the position. As Rose-Ackerman and Tan noted, structural reforms that reduce corrupt incentives ought to be the centrepiece. ${ }^{151}$ Laws against bribery are vital, but they cannot have a lasting positive impact unless coupled with underlying institutional and deep reform. ${ }^{152}$ Developing an independent judiciary is essential to strengthening the rule of law by forestalling corruption. ${ }^{153}$ More challengingly, reforms will be strongly resisted by the current beneficiaries who would lose their power to extract favours. ${ }^{154}$ If China is to build a legitimate democracy, norms must change, including political ones. It remains uncertain whether state capitalism can stand the test of legal globalisation for a real fundamental transformation. In this regard, Hong Kong and Singapore act as successful models given that they have been benefiting from the rule of law, independent judiciary and zero tolerance for corruption. ${ }^{155}$

\subsection{The Shifting Landscape of Localised Compliance Risks}

Culture is arguably resistant to institutional changes. It can hardly be affected simply by changes in new laws. Anti-bribery results depend upon the extent to which the company's incentives are tied to its performance. There is need for a broader and multijurisdictional compliance scenario. Otherwise, foreign MNCs would be misled and further suffer without an adequate corresponding global antibribery governance regime. Fostering a culture of compliance enables multinationals to localise their global anti-bribery mechanisms compatibly into China's sociolegal and cultural settings and transform the anti-bribery system. The GSK case highlights broader concerns about the challenges of completing a compatible transformation. ${ }^{156}$ Through fostering the culture that fuses high integrity, MNCs will likely able be to complete the process of such a transformation.

\subsubsection{A Lesson from the GSK's Failure in its Global Compliance Strategy}

There is a growing threat from domestic laws in China, as illustrated by a highprofile prosecution of GlaxoSmithKline (GSK) in 2014. The GSK case highlights the compliance challenges faced by foreign MNCs operating in China. Arguably, there are many factors that might have led to this enforcement. A possibility of the selective enforcement cannot be precluded in the context of China's desire to reduce

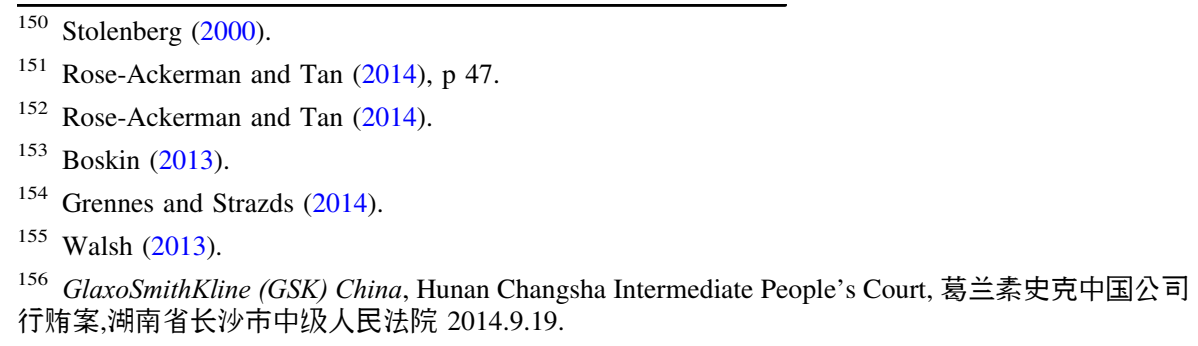


healthcare costs. There might be an element of nationalism, and even protectionism, since local firms are normally at a disadvantage compared to foreign MNCs with renowned brands and reputations. ${ }^{157}$ It is also notable that China's fragmented drug licensing system provides ample room for rent seeking. ${ }^{158}$ Nevertheless, the GSK's local compliance system failed to properly detect potentially hundreds of millions of pounds worth of bribes. GSK once announced that its internal probe had found no evidence of bribery, and claimed to be observing codes of its integrity and ethical standards. This only provides reductio ad absurdum, which clearly illuminates the gaps between corporate anti-bribery policy and its effective implementations. ${ }^{159}$ It indicates that GSK needs more than a well-written programme, but the creation of a dynamic and strong culture which facilitates compliance.

The GSK case acts as a wake-up call for foreign MNCs, largely because it has not perceived bribery in China as a serious compliance risk, especially when compared to a potential BA 2010 or FCPA violation. ${ }^{160}$ The crackdown on GSK's bribery suggests that the Chinese enforcement agencies have given teeth to their own antibribery laws. ${ }^{161}$ Although the People's Courts are occasionally biased in favour of local defendants, Chinese anti-bribery efforts cannot be caricatured as purely protectionist efforts to limit competition from foreign MNCs. ${ }^{162}$ Furthermore, the GSK case serves as a perfect example endorsing the Ninth Amendment that the focus of anti-bribery in China is shifting from bribe takers to bribe givers. MNCs' compliance programmes in responses only to FCPA and BA 2010 are apparently no longer sufficient. A corporate compliance programme aimed at addressing only the prohibitions embodied in the two Acts is destined to fall short in China. More problematically, any anti-bribery enforcement in China is likely to trigger FCPA and BA 2010 investigations that will have massive repercussions across significant international business. Finally, the enforcement agencies give meaningful credit to companies which implement in good faith a comprehensive and risk-based compliance programme.

Assessment of risk is fundamental to developing a strong compliance programme, ${ }^{163}$ which need to be updated to ensure it accounts for anti-bribery risks on a global basis. Mere global compliance programmes superimposed upon China's regulatory environment are inadequate. MNCs must assess the bribery risk of each jurisdiction where they operate. Failure to take these steps will result in exposure to massive bribery liability on a global scale. It is imperative for an MNC to enhance the due diligence process in dealing with the presence of any red flags. ${ }^{164}$

\footnotetext{
157 Dawar and Frost (1999).

158 Hook (2013).

159 Rose-Ackerman and Tan (2014).

160 Chow (2012).

161 Schipani et al. (2016).

162 Chow (2014).

163 FCPA Guidance, p 58.

164 Serious Fraud Office v. Standard Bank Plc, No. U20150854, Southwark Crown Court, United Kingdom, 30 November 2015, https://www.sfo.gov.uk/cases/standard-bank-plc/bank_Preliminary_1.pdf.
} 
Although the adequate compliance subjects a company to the least amount of exposure to criminal liability, the short-term commercial incentive renders it unattractive for the entity to adhere to such strategies. It is unlikely to inhibit every employee from acting outside of the parameters of a company's compliance policy. ${ }^{165}$

\subsubsection{The Feasibility to Foster a Compliance Culture against Bribery}

It is highly feasible to design a set of anti-bribery compliance rules, which has farreaching implication for MNCs with global presence. The cultural dimension is important to the implementation of a compliance programme, given that cultures exert a powerful influence on the corporate behaviour. The impact encompasses changes in both formal institutions and laws and MNCs' legal behaviour. The strong tradition of gift-giving creates a high-risk corrupt business environment. Globalising anti-bribery compliance efforts will mitigate the risks. However, delivering the antibribery culture is a challenging area and also difficult to quantify. It could contribute to bribery, while the cultural elements, to some extent, rationalise such behaviour. Whilst not running afoul of the FCPA or the BA 2010, MNCs must understand the cultural uniqueness that shapes business transactions in China. Seeking to transform social norms, MNCs' willingness to nurture a corporate culture of zero-tolerance for bribery is in fact contrary to the Chinese local customs and is thus doomed from the start. ${ }^{166}$ Despite significant cultural differences between the jurisdictions, the UK, China and the US anti-bribery authorities face challenges that are leading to convergence in enforcement approaches. Differences in cultural values may increase the likelihood of violations of anti-bribery law, but do not necessarily create practical problems in extraterritorial enforcement. ${ }^{167}$ Overestimation of the cultural variable would not only compromise the Chinese institutional globalisation of anti-bribery law, but also comprise the localisation of MNCs' global compliance efforts in China.

Convergence on a single set of cultural norms seems to be highly implausible. ${ }^{168}$ To achieve purportedly objective righteous conduct, hard law to criminalise bribing foreign officials can ultimately not only transcend the cultural distinctions, but also restrain certain cultural declination for unlawful behaviour. ${ }^{169}$ It is critical to make integrity and ethics a part of the overall evaluation scheme, which provides positive incentives for compliance. Foreign MNCs' success will require more than simply developing greater cultural sensitivity. ${ }^{170}$ The Siemens case provides a notorious example of a failure to implement such a policy, under which bribery was tolerated

\footnotetext{
165 Henning (2012).

166 Schipani et al. (2016).

167 Runnels and Burton (2012).

168 Nichols (1997).

169 Cao (2016), p 145.

170 Krishnarao Prahalad and Lieberthal (2003).
} 
and rewarded at the highest levels of the company. ${ }^{171}$ A policy of zero tolerance for bribery is the most effective way to comply on a global scale. Such a policy renders MNCs' compliance exceedingly challenging, especially during a global recession. A high-level of commitment is required to prevent persons acting on the firms' behalf from engaging in bribery, and to foster a corporate culture in which bribery is never tolerated. ${ }^{172}$ MNCs' subsidiaries and branches must show evidence of their commitment to a culture of compliance.

\subsubsection{Make the Global Compliance Regimes Compatible}

With global presence, it will never be enough to highlight the compatible integration of the MNCs' global compliance into the local anti-bribery framework. Various developments in the Chinese legal enforcement landscape suggest that compatible anti-bribery compliance need to be warranted. To mitigate the risks, MNCs must turn to the aphorism 'think global, but act local' ${ }^{173}$ Bribery per se may not be a cultural issue, it is imperative to integrate the specifics of a given culture into an anti-bribery compliance programme and, specifically, its implementation. The challenge is to adapt compliance programmes to specific environments while respecting the same standards and principles of integrity. Bribery presents legal and regulatory challenges, but these challenges cannot be addressed by the law in isolation. It is imperative to integrate MNCs' compliance programmes by efficiently tailoring their efforts into the local legal and enforcement settings. An integrity system integrates a set of mechanisms that both reinforce desired behaviour via a value-orientated cultural path and deter bribery via rule-based law enforcement. ${ }^{174}$ The compatible integration needs to be carefully adapted for the Chinese market and designed for effective implementation. Inevitably, implementation of an adequate anti-bribery compliance programme may be resisted in particular, when a foreign MNC ensures that bribery is not countenanced so as to reduce the incidence of passive and active bribery. ${ }^{175}$ There is no one-size-fits-all compliance approach. It takes time for the current global anti-bribery regime to converge on a set of conceptual standards for theoretically defining corruption, given the universal disapproval of bribery. ${ }^{176}$ Most foreign MNCs may have to adjust their focus on compliance, which used to be driven primarily by external influences, such as under the BA 2010 and the FCPA, rather than Chinese legislation.

\footnotetext{
171 SEC, 'SEC Charges Siemens AG for Engaging in Worldwide Bribery' (15 December 2008), https:// www.sec.gov/news/press/2008/2008-294.htm; DoJ, 'Siemens AG and Three Subsidiaries Plead Guilty to Foreign Corrupt Practices Act Violations and Agree to Pay $\$ 450$ Million in Combined Criminal Fines' (15 December 2008), https://www.justice.gov/archive/opa/pr/2008/December/08-crm-1105.html; Warin et al. (2010a), p 56.

172 Serious Fraud Office (SFO) (2011), p 89.

173 Park and Vanhonacker (2007).

174 Paine (1994).

175 Bribery Act 2010 Guidance $\S 10$, p 8.

176 Salbu (1999), p 241.
} 


\section{Conclusion}

This study presents a cultural analysis of bribery as an essential tool for shaping an effective legal apparatus. The global community has taken a more streamlined and unified approach toward bribery, that is, objections to bribery are commonly shared. There has been a convergence of global anti-bribery norms toward outlawing the bribery of foreign officials. The pace of consolidating domestic institutions is escalating as globalisation continues. An international avenue could be feasible for enhancing the enforcement mechanism in addressing transnational bribery. Some primary anti-bribery laws, like the BA 2010 and the FCPA, do not necessarily put the American and British corporations in a disadvantaged position in terms of global competitiveness.

MNCs trying to embed ethical values into compliance regimes will need to consider the particular cultural characteristics and Confucian influences on employees' behaviour. However, China's culture represents only one of the variables that are likely to contribute to bribery. A defence in the form of cultural accommodation used by foreign MNCs, should not be well justified. While cultural sensitivity to China's anti-bribery laws is imperative, MNCs must cover the overlap across jurisdictions. Regardless of the plausible 'mother of all path dependence', culture does not play a decisive role in building China's anti-bribery laws following the track of the FCPA and the BA 2010, nor will culture be considered as a mitigating element in the cross-border corporate criminal liability. The mitigation considerations enshrined in both the Bribery Act Guidelines and FCPA Guidance remain the same, in substance, as rationales behind China's guanxi-oriented cultures. In practice, such circumstances are usually blurred, where it is nearly impossible to ascertain what kind of payment could constitute bribery, and what could be acceptable as regular gifts or hospitality. The softened interpretations by the Guidance complicate the global anti-bribery efforts, despite the golden rule of 'prevention is better than cure'.

Anti-bribery is a section within a wide range of inroads that travel to the heart of the institutional cultures of MNCs, of which ethical culture should be clearly articulated. MNCs should have rigorous and well-established compliance programmes. To mitigate the exposure to litigation risks requires a relentless focus on compliance. Adequate compliance culture can protect against violations and help mitigate liability in case bribery should arise, while a most reliable approach is to enhance institutional building in compliance programmes. This approach is neither dichotomous nor between a rock and a hard place. Anti-bribery efforts are still in their infancy in China, but are likely to grow as the world trends towards a greater emphasis on ethically responsible global business practices. It holds particularly true with the Chinese government prioritising its campaign against the prevalence of corruption. MNCs should ensure that their due diligence and compliance programmes rise to this new challenge. The increasingly aggressive enforcement of the global anti-bribery law unquestionably poses further challenges for MNCs operating in China. This leads MNCs to re-evaluate their anti-bribery programmes 
to ensure adequate compliance. This highlights a renewed focus on the importance of MNCs' effective compliance strategies for their long-term success globally.

Open Access This article is distributed under the terms of the Creative Commons Attribution 4.0 International License (http://creativecommons.org/licenses/by/4.0/), which permits unrestricted use, distribution, and reproduction in any medium, provided you give appropriate credit to the original author(s) and the source, provide a link to the Creative Commons license, and indicate if changes were made.

\section{References}

Andrulis R, Quanyu H, Tong C (1994) A guide to successful business relations with the Chinese: opening the great wall's gate. Routledge, New York

Ashe DP (2005) The cultural sensitivity card is often played by foreign MNCs which pay bribes in achieving their profit-maximising goals. Fordham Law Rev 73(6):2897-2945

Boskin M (2013) The global stake in China's anticorruption reform. Project Syndicate, 10 September 2013. https://www.project-syndicate.org/commentary/bo-xilai-and-the-anti-corruption-fight-inchina-by-michael-boskin?barrier=accessreg/. Accessed 29 Aug 2017

Cao L (2016) Culture in law and development: nurturing positive change. Oxford University Press, Oxford

Carling J, Paasche E, Siegel M (2015) Finding connections: the nexus between migration and corruption. http://www.migrationpolicy.org/article/finding-connections-nexus-between-migration-andcorruption. Accessed 29 Aug 2017

Chafuen A, Guzman E (2000) Economic freedom and corruption. In: O'Driscoll G Jr, Nolmes K, Kirkpatrick M (eds) 2000 index of economic freedom. The Heritage Foundation, Washington DC

Chow D (2012) The interplay between China's anti-bribery laws and the Foreign Corrupt Practices Act. Ohio State Law J 73:1015-1017

Chow D (2014) Why China's crackdown on commercial bribery threatens US multinational companies doing business in China. Ariz J Int Comp Law 31(3):511-545

Davis K (2010) Does the globalization of anti-corruption law help developing countries? In: Faundez J, Tan C (eds) International law, economic globalisation and development. Edward Elgar, Northampton, pp 283-306

Dawar N, Frost T (1999) Competing with giants: survival strategies for local companies in emerging markets. Harv Bus Rev 77:119

Deming SH (1999) international legal developments in review: foreign corrupt practices. Int Lawyer 33:507-514

Donaldson T (1996) Values in tension: ethics away from home. Harv Bus Rev 74:48-64

Fort T, Noone J (2000) Gifts, bribes, and exchange: relationships in non-market economies and lessons for pax e-commercia. Cornell Int Law J 33:515-546

Gartland A (2014) Bribery and corruption: caught between three regimes. Practical Law, 24 October 2014

Grennes T, Strazds A (2014) Why is corruption more prominent in some countries than others? EconoMonitor, 11 December 2014. http://www.economonitor.com/thoughtsacrossatlantic/2014/12/ 11/why-is-corruption-more-prominent-in-some-countries-than-others/. Accessed 29 Aug 2017

Guthrie D (1998) The declining significance of guanxi in China's economic transition. China Q 154:254282

Hamilton G (1994) Civilizations and the organization of economics. In: Smelser NJ, Swedberg R (eds) The handbook of economic sociology. Princeton University Press, Princeton, pp 183-205

Hamilton G (2006) Commerce and capitalism in Chinese societies. Routledge, London

Hansen C (1992) A Daoist theory of Chinese thought: a philosophical interpretation. Oxford University Press, New York

Henning P (2012) Be careful what you wish for: thoughts on a compliance defence under the Foreign Corrupt Practices Act. Ohio State Law J 73(5):883-928

Hook L (2013) Unorthodox injections sustain China's healthcare system. Financial Times, 16 July 2013

Hsu C (2005) Capitalism without contracts versus capitalists without capitalism: comparing the influence of Chinese guanxi and Russian blat on marketization. Communist Post-Communist Stud 38(3):309_ 327 
Johnston M, Hao Y (1995) China's surge of corruption. J Democr 6(4):80-94

Krishnarao Prahalad C, Lieberthal K (2003) The end of corporate imperialism. Harv Bus Rev 81(8):109117

Li K (2011) Performing bribery in China: guanxi practice, corruption with a human face. J Contemp China 20(68):1-20

Lieberthal K (1996) Politics and economics in China. In: Joint Economic Committee, Congress of the United States (ed) China's economic future: challenges to US policy. M.E. Sharpe, Armonk, pp 1115

Lin X, Malhotra S (2012) To adapt or not adapt: the moderating effect of perceived similarity in crosscultural business partnerships. Int J Intercult Relat 36(1):118-121

Marcoux J-S (2009) Escaping the gift economy. J Consum Res 36:671-685

Matthews C (2013) China releases interpretation on anti-bribery enforcement. Wall Street Journal, 3 January 2013

Mautner M (2011) Three approaches to law and culture. Cornell Law Rev 96:839-867

Michaels R (2013) Globalisation and law: law beyond the state. In: Banakar R, Travers M (eds) Law and social theory, 2nd edn. Hart, Oxford, pp 287-303

Michailova S, Worm V (2003) Personal networking in Russia and China: blat and guanxi. Eur Manag J 21(4):509-519

Montigny P (2015) Is corruption a cultural issue? Ethic Intell, 15 April 2015. http://www.ethicintelligence.com/blog/8291-corruption-cultural-issue/. Accessed 29 Aug 2017

Nichols P (1997) The viability of transplanted law: Kazakhstani reception of a transplanted foreign investment code. Univ Pa J Int Econ Law 18(4):1235-1297

Nichols P (1999a) A legal theory of emerging economies. Va J Int Law 38(2):229-302

Nichols P (1999b) Are extraterritorial restrictions on bribery a viable and desirable international policy goal under the global conditions of the late twentieth century? Increasing global security by controlling transnational bribery. Mich J Int Law 20:451-476

Nichols P (1999c) Regulating transnational bribery in times of globalization and fragmentation. Yale J Int Law 24(1):257-278

Noonan J Jr (1984) Bribes: the intellectual history of a moral idea. Diane Publishing Company, Collingdale

Norton P (2006) The Foreign Corrupt Practices Act dilemma. China Bus Rev 33(6):22

OECD (2008) Corruption: a glossary of international standards in criminal law. OECD Publishing, Paris

OECD (2014) OECD Foreign bribery report: an analysis of the crime of bribery of foreign public officials. 2 December 2014. http://www.oecd.org/corruption/oecd-foreign-bribery-report9789264226616-en.htm. Accessed 29 Aug 2017

OECD Anti-Corruption Unit (1998) Commentaries on the Convention on Combating Bribery of Officials in International Business Transactions. Int Legal Mater 37:8

Paine L (1994) Managing for organisational integrity. Harv Bus Rev 92(2):106-117

Park SH, Vanhonacker WR (2007) The challenge for multinational corporations in China: think local, act global. MIT Sloan Manag Rev 48(4):W8-W15

Pearce J, Xin K (1996) Guanxi: connections as substitute for formal institutional support. Acad Manag J 39(6):1641-1658

Pedersen E (2008) The Foreign Corrupt Practices Act and its application to US business operations in China. J Int Bus Law 7(1):13-47

Perry E (2007) Studying Chinese politics: farewell to revolution? China J 57:1-22

Posner R (1980) A theory of primitive society, with special reference to law. J Law Econ 23(1):1-53

Posner R (2007) Economic analysis of law, 7th edn. Aspen Publishers, New York

Richardson D, Tepikina A (2014) Anti-corruption campaign in China-causes of corruption, and hope? SEC Actions, 25 August 2014. http://www.secactions.com/anti-corruption-campaign-in-chinacauses-of-corruption-and-hope/. Accessed 25 Aug 2017

Rose C (2015) International anti-corruption norms: their creation and influence on domestic legal systems. Cambridge University Press, Cambridge

Rose-Ackerman S (2010) Corruption: greed, culture and the state. Yale Law J Online 120:125-140

Rose-Ackerman S, Tan Y (2014) Corruption in the procurement of pharmaceuticals and medical equipment in China: the incentives facing multinationals, domestic firms, and hospital officials. UCLA Pac Basin Law J 32(1):1-54 
Runnels M, Burton A (2012) The Foreign Corrupt Practices Act and new governance: incentivizing ethical foreign direct investment in China and other emerging economics. Cardozo Law Rev $34: 295-327$

Salbu S (1999) Extraterritorial restriction of bribery: a premature evocation of the normative global village. Yale J Int Law 24(1):223-255

Salbu S (2000) A delicate balance: legislation, institutional change, and transnational bribery. Cornell Int Law J 33:657-678

Schipani C, Liu J, Xu H (2016) Doing business in a connected society: the GSK bribery scandal in China. Univ Ill Law Rev 1:63-102

Schramm M, Taube M (2003) The institutional economics of legal institutions, guanxi, and corruption in the PR China. In: Kidd J, Richter F-J (eds) Fighting corruption in Asia: causes, effects, and remedies. World Scientific, Singapore, pp 271-348

Serious Fraud Office (SFO) (2011) Serious economic crime: a boardroom guide to prevention and compliance. White Page Ltd, London, London

Serious Fraud Office (SFO) (2012) Business expenditure. 9 October 2012. https://www.sfo.gov.uk/ publications/guidance-policy-and-protocols/bribery-act-guidance/

Silver-Greenberg J, Protess B (2013) JP Morgan hiring put China's elite on an easy track. The New York Times, 29 August 2013

Smart A, Hsu C (2007) Corruption or social capital? Tact and the performance of guanxi in market socialist China. In: Juijten M, Anders G (eds) Corruption and the secret of law: a legal anthropological perspective. Ashgate, Burlington, pp 167-190

Steidlmeier P (1999) Gift giving, bribery and corruption: ethical management of business relationships in China. J Bus Ethics 20(2):121-132

Stevenson D, Wagoner N (2011) FCPA sanctions: too big to debar? Fordham Law Rev 80(2):775-820

Stolenberg C (2000) Globalization, Asian values, and economic reform: the impact of tradition and change on ethical values in Chinese business. Cornell Int Law J 33(3):711-729

Tan J, Wang D (2015) Anti-corruption dragnet widens. Insight, 3 November 2015

Torres-Fowler RZ, Anderson K (2011) The Bribery Act's new approach to corporate hospitality. Va J Int Law Dig 52:39-53

Vega M (2009) The Sarbanes-Oxley Act and the culture of bribery: expanding the scope of private whistleblower suits to overseas employees. Harv J Legis 46:425-454

Wallace-Bruce NL (2000) Corruption and competitiveness in global business-the dawn of a new era. Melb Univ Law Rev 24(2):349-354

Walsh C (2013) The Hong Kong model: former official suggests area may fuel reforms in China. Harvard Gazette, 25 February 2013

Wan W (2012) China's new leaders focus on culture of corruption. Washington Post, 29 December 2012

Warin FJ, Diamant MS, Pfenning JM (2010a) FCPA compliance in China and the gifts and hospitality challenge. Va Law Bus Rev 5(1):33-80

Warin FJ, Falconer C, Diamant M (2010b) The British are coming: Britain changes its law on foreign bribery and joins the international fight against corruption. Tex Int Law J 46:1-72

Wedeman A (2005) The intensification of corruption in China. China Q 180:920

Weiss D (2009) The Foreign Corrupt Practices Act, SEC disgorgement of profits, and the evolving international bribery regime: weighing proportionality, retribution, and deterrence. Mich J Int Law 30:471-506

Windsor D, Getz K (2000) Multilateral cooperation to combat corruption: normative regimes despite mixed motives and diverse values. Cornell Int Law J 33(3):731-772

Wombolt K, Galvin M (2012) Why multinational must be wary of China's anticorruption authorities. International Financial Law Review, 30 January 2012

World Bank (2015) Doing business 2015 going beyond efficiency, 12th edn. World Bank Group, Washington DC

Yang MM (1994) Gifts, favours, and banquets: the art of social relationships in China. Cornell University Press, Ithaca

Yang JZ (1999) When MNCs come to China, who changes whom? China Bus Rev 26:16-19

Yarosky H (1964) The criminal liability of corporations. McGill Law J 10(2):142-157

Yeung IY, Tung R (1996) Achieving business success in Confucian societies: the importance of guanxi (connections). Organ Dyn 25(2):54-65

Zhan V (2012) Filling the gap of formal institutions: the effects of guanxi network on corruption in reform-era China. Crime Law Soc Change 58(2):93-109 